\title{
Islamic and conventional banks stability: a comparative analysis
}

\author{
Teguh Santoso $^{1 *}$, Irlan Adiyatma Rum ${ }^{1 *}$, Kinanti Z Patria ${ }^{2}$
}

${ }^{1}$ Center of Economics and Development Studies, Universitas Padjajaran
${ }^{2}$ Undergraduate Student, Departement of Economics, Universitas Padjajaran
${ }^{*}$ Corresponding authors: teguh.santoso@ @unpad.ac.id, adiyatmarum@gmail.com

\section{ABSTRACT}

This paper attempts to measure the financial stability for Islamic and conventional banks and compare the result of financial stability between the two kinds of banks. In this study, financial stability will be measured using $\mathrm{z}$-scores. The data sample used in this study include four Indonesian Islamic banks and four Indonesian conventional banks, which is represent by two larger banks and two smaller ones. After z-score is calculated, descriptive statistic and stationarity tests were also conducted to compare the stability results for both banks. A comparative study shows that conventional banks is maybe more stable than Islamic banks. Regression analysis using fixed effect model were conducted to investigate the factors influencing banks stability. Regression result shows the factor which have a significant influence to banks stability are Islamic dummy, size of banks and cost to income ratio. Although other variables such us credit to asset ratio, income diversity and Islamic banks income diversity have no significant effect to banks stability, they have the correct signs.

Keywords: Islamic banks, conventional banks, stability, z-score, panel data

\section{INTRODUCTION}

Stability on banking industry affects the effectiveness of the conduct in monetary policy (Warjiyo, 2000). It is showed by the conduct of banking function as the intermediaries institution for realocating funds from society to another form of funding product could work well. It is necessary to know how stable is the banking industry to accomodate the conduct of monetary policy. In the banking industry cycle, islamic banks in conjunction with conventional banks have an important role for maintaining the monetary policy.
The most common characteristic that distinguish islamic and conventional banks is the existence of interest. Islam banks which follow islam laws avoid all transactions which contain interest, replacing it by profit or loss sharing and goods services trading (Siddiqi 2000). The power of islamic banks has been proven by the great history of islamic banks written through financial crisis whereas almost all conventional bank fails, no single islamic bank does.

In Malaysia, islamic banks are significantly correlated to the long run economic growth and capital accumulation, and causes this country to become international islamic financial hub (Hafas, 2009). A research by Beck, Demirgüç-kunt, \& Merrouche (2013) accross 22 countries, including Indonesia, shows that Islamic banks have higher intermediation efficiency, lower cost efficiency, lower non-performing loans and higher capitalization - those affect the result of z- scores to become higher which indicates the low risk of bank insolvency.

Cihak and Hesse (2008) conducted cross country studies of Islamic banks impact on financial stability. Using $\mathrm{z}$-scores as a measurement of stability, their study found that (i) small Islamic banks tend to be financially stronger than small commercial banks; (ii) large commercial banks tend to be financially stronger than large Islamic banks; and (iii) small Islamic banks tend to be financially stronger than large Islamic banks

The difference of system between conventional and islamic banks have different effect to their stability. There is no clear consensus in the literature on the question of whether Islamic banks are more or less stable than conventional banks (Ghassan, Fachin, \& Guendoz, 2013). The power of islamic banks could 
not represent the stablization of the industry. Thus, research is needed to fill this gap.

Indonesia, where Islam has a dominant role in its society's life is an interesting setting to conduct research on the islamic banking industry. There are 11 Islamic banks in Indonesia which operate using dual banking system based on API (Arsitektur perbankan Indonesia). This study tries to answer the question of whether the Islamic banks are more or less stable than the conventional ones, using the sample four Indonesian conventional banks and four Indonesian Islamic banks.

This research is using $\mathrm{Z}$-score methods to measure financial stability. A higher z-score corresponds to a lower upper bound of insolvency risk - a higher z-score therefore implies a lower probability of insolvency risk (Cihak and Hesse, 2008). This method is very useful to show the condition when a company or firm is going to get insolvency which is related to stability. This study also attempts to identify the factors that influence the stability. Using pooled model, we will estimate which are the factors that have influence on both conventional and Islamic banks.

\section{METHODS}

Stability measurement in this study is using ZScore. The Z Score has become a popular measurement for bank soundness (Boyd and Runkle, 1993; Maechler, Mitra, and Worrell, 2005 and Cihak and Hesse, 2008). In the literature of Islamic Banking, this indicator is first used empirically by Cihak and Hesse (2008), but theoretically had been discussed by Mirakhor (1987, see Gamaginta and Rokhim, 2011). Cihak and Hesse (2008) define z-core as:

$$
Z=\frac{(k+\mu)}{\sigma}
$$

where $\mathrm{k}$ is equity capital and reserves as percentage of assets, $\mu$ is average return as percentage of assets, and $\sigma$ is standard deviation of return on assets as a proxy for return volatility. According to Yeyati and Micco (2007), a smaller Z-score (a greater risk exposure) can be associated with narrower returns (for example, because of larger inefficiencies or reduced market power), a larger return volatility (due to poorer diversification or a less conservative investment option), or a higher level of leverage (due to lower capitalization).
As a first step in this study, we perform basic statistical tests for the z-scores and compare zscores in Islamic and conventional banks. To examine the robustness of the result in the first step, we conduct standard deviation analysis. The underlying idea behind these alternative approaches is that the standard deviation underlying the z-score gives only a part of the information about the behavior of z-scores (Hesse and Cihak,2007; Cihak and Hesse, 2008). As a second step, we use regression analysis to see some additional factors that explain bank-to-bank variation in z-scores. In this step, fixed effect panel regression model will be applied. The specification model of fixed effect model (FEM) is as follows:

$Z_{i t}=\beta_{0}+\beta_{1}$ Asset $_{i t}+\beta_{2} C A_{i t}+\beta_{3} C I_{i t}+$ $\beta_{4} I D_{i t}+\varepsilon_{i t}$

where the dependent variable is the z-core, $Z_{i t}$. All of the independent variables reflect industry variables for all banks. There are total asset for bank $i$ at time $t$, credit to asset ratio (CA) for bank i at time $t$, cost to income ratio (CI) for bank $i$ at time $\mathrm{t}$ and income diversity for bank $\mathrm{i}$ at time $\mathrm{t}$. CA is percentage of total credit to total asset of each bank. For Islamic banks, credit activity refers to lending with the Murobahah and Mudharobah scheme. $\mathrm{CI}$ is percentage of total operational cost to total operational income and ID is income diversity. Income diversity is useful to control for differences in the structure of the bank's income (Laeven and Levine, 2005; Cihak and Hesse, 2008). This variable captures the degree to which banks diversify from traditional lending activities (those generating net interest income) to other activities (Cihak and Hesse, 2008). Income diversity measure is defined as follows:

$I D=1-\frac{(\text { Net interest income-other operating income })}{\text { total operating income }}$

For Islamic banks, net interest income is replaced by income from fund disbursement. Higher value of ID variable corresponds to a higher degree of diversification.

Our data set includes four Islamic Banks, namely Muamalat Bank, Bank Syariah Mandiri, Bank Syariah Bukopin and Bank BRI Syariah. The availability of data series is the reason we choose the bank samples - only four Islamic banks that have more than 30 series data (quarterly). For conventional banks, we use also four bank samples, namely Panin Bank, OCBC Bank, Index Selindo Bank and Agris Bank. They are relatively at the 
same category based on core capital which is based on the grouping of General Bank Business Classification (Bank Umum Kategori Usaha/BUKU). The source of data is from the quarterly financial report from each bank, for $2008 \mathrm{q} 1-2016 \mathrm{q} 2$. Length of the data series can show the variability and volatility of the stability score.

\section{RESULTS AND DISCUSSIONS}

In the first step we will discuss about $\mathrm{z}$ score, test equality of mean between Islamic and conventional banks. The basic data analysis suggest that conventional banks may be more stable than conventional banks. Conventional banks z score on average higher than Islamic banks (Table 1).

\section{Table 1: Test of Equality of Mean}

The lower $\mathrm{z}$ score Islamic banks on average may be caused by the lower value of ROA, Equity to Asset Ratio and the higher of standar deviation. We have calculated ROA, Equity to Asset Ratio (E/A) for Islamic and conventional banks at the sample period.

\section{Table 2: Descriptive Statistic for ROA and EA}

Table 1 shows that even z score for Islamic banks is lower than conventional banks. However, Islamic banks have, on average, higher loan to asset ratios than conventional banks. This condition reflects the fact that Islamic banking prohibits investments in non-lending operations such as regular bonds, exchange market and derivative or trading asset.

Islamic banks have higher cost to income ratio than conventional banks. This result suggests that Islamic bank in the sample period is relatively less efficient than conventional banks. But this result have to be further analyzed using particular tools, especially in terms of efficiency analysis. However, at least, this finding also support the previous study, which found that Islamic banks are less efficient than conventional banks (Mokhtar, Abdullah and Alhabshi, 2006; Johness, Izzeldin and Pappas, 2012).

For the income diversity, there is no significant difference between Islamic and conventional banks. The lower value of income diversity shows that both Islamic banks and conventional banks still depends on the traditional (lending) activity in order to maximize their profit. In other words, both banks do not yet maximize the other source of income, such a fee based and transaction banking.

To examine the finding in the previous step, we have also used another way to measure the stability of $\mathrm{z}$ score. Stationarity test of $\mathrm{z}$ score was conducted to measure the stability of the $\mathrm{z}$ score of both banks. The stationary of data is data which have a mean, variance and autovariance that remain constant at any time the data was created or used. When the data are stationary, then the data can be said to be more stable

Following Hassan, Fachin and Guendoz (2012), unit root test by applying ADF-GLS was conducted to test the stationarity of $\mathrm{z}$ score both of banks. As presented on the Table 3, z score for Islamic banks appears to be non-stationary in the level (ADF t stat $<$ Mc Kinnon Critical Value at 5\%). On the opposite, $\mathrm{z}$ score for conventional is stationary in the level (ADF t stat < Mc Kinnon Critical Value at $5 \%$ ). Based on ADF test, due to $\mathrm{z}$ score for conventional that is stationary and $\mathrm{z}$ score for Islamic banks that is non-stationary, we may conclude that $\mathrm{z}$ score for conventional banks may be more stable than Islamic banks. These result confirm the result of the test quality of mean in the previous step.

\section{Table 3: Stationarity Test for Z Score}

The previous results are useful to compare the stability between Islamic and conventional banks, but may overlook some additional factors that explain bank-to-bank variation in $\mathrm{Z}$-scores. Therefore, we will examine this issue more formally using regression with Fixed Effect Model (FEM).

\section{Table 4: Regression Result (Fixed Effect Model)- Dependent Variable: $\mathrm{Z}$ Score}

These regression results identify that factors which are significant in determining $\mathrm{z}$ score for both banks are Islamic dummy, total asset and cost to income ratio. Even the other variables that are not statistically significant, they generally generally the expected signs.

A negative relation and statistically significant at $1 \%$ level for Islamic Dummy confirm from the simple comparison of test of equality of mean and stationarity test, that conventional banks tend to be more stable than Islamic banks. These results confirm the first step due to the larger difference in 
mean of $\mathrm{z}$ score between Islamic and conventional banks.

Total asset have significant effect at $10 \%$ level and a positive relation to banks stability. The higher the asset of a bank, the bank will tend to br more stable than the smaller one. As the main business of the banks is managed for a risk, the greater the bank's assets, the greater the ability to absorb risk and improve the stability of the bank. This result supports Cihak and Hesse (2008) finding, that total asset have a positive relation and significant effect to bank stability.

Variable credit (loan) to asset ratio have a negative sign but statistically not significant. Even as there is no significant effect, this variable have a correct sign. The same result is also found by Cihak and Hesse (2008) - if all of banks (Islamic and conventional banks) are regressors in one model, variable credit to asset ratio have a negative sign but not significant effect. If a bank have high credit (loan), this bank will be more probable to insolvent due to probability of default from credit activity.

Variable cost to income ratio have a negative and significant effect at $10 \%$ level. Banks with higher cost to income tend to have lower z-scores. Cost to income ratio as a proxy of efficiency shows that the greater cost to income ratio, then banks will be increasingly inefficient. Inefficiency will lead to increased operating costs, thereby decreasing profitability and will result in lower z score

Income diversity have a negative impact but statistically not significant. This variable has a correct sign influence to bank stability. A small influence on the $\mathrm{z}$ score shows that both of banks still depend on traditional or lending activity to maximize profit. Non-operating income, have not been maximized. For Islamic banks, income diversification also have no effect on bank stability. These results prove that Islamic bank in Indonesia have not been optimized to operate income to generate profit.

\section{CONCLUSION}

This paper has presented an empirical study about the comparison of financial stability between Islamic and conventional banks and the influencing factors. We conduct two steps: in the first step we use statistic descriptive analysis to see the difference in stability. Using test of equality of mean, we noted that Islamic banks are less stable than conventional banks. To confirm the result of statistic descriptive analysis, we also conduct the stationarity test to measure the stability of $\mathrm{z}$ score. The result of stationarity test also support the previous finding that conventional banks in this sample are more stable than Islamic banks. We also conducted regression analysis, fixed effect model to identify the factors that influence the stability. The factors that have significant effect to banks stability are Islamic dummy, size bank (total asset) and cost to income ratio. The other variables, namely credit to asset ratio, income diversity and income diversity for Islamic banks, have no significant effect to stability. The limitation of this study are the availability of the data series for Islamic banks and the model specification. In further research, we suggest for using more samples of bank and conducting Dynamic Panel Data Analysis.

\section{ACKNOWLEDGEMENT}

We would like to thank the Chair of Committee and Chair of Scientific Commite of ICIMM 2016, Dr. Adiatma Siregar and Prof. Dr. Tati S Joesron that have offered an opportunity for the authors to present our paper.

\section{REFERENCES}

Ahmad, A. U. F., \& Hassan, M. K. (2007). Riba and Islamic banking. Journal of Islamic Economics, Banking and Finance, 3(1), 1-33.

Beck, T., Demirgüç-kunt, A., \& Merrouche, O. (2013). Islamic vs . conventional banking: Business model, efficiency and stability. Journal of Banking and Finance, 37(2), 433447.

Boyd, John H., and David E. Runkle, 1993, "Size and Performance of Banking Firms,"Journal of Monetary Economics, Vol. 31, pp. 47-67.

Fachin, H. B. G. S., \& Guendoz, A. A. Financial Stability of Islamic and Conventional Banks in Saudi Arabia: a Time Series Analysis. DSS Empirical Economics and Econometrics Working Papers Series. DSS-E3 WP 2013/1

Furqani, H., \& Mulyany, R. (2009). Islamic banking and economic growth: Empirical evidence from Malaysia. Journal of Economic Cooperation and Development, 30(2), 59-74. 
Gamaginta, Rokhim. R.(2011) The stability comparison between Islamic banks and conventional banks: Evidence in Indonesia. In: proceedings of the 8 th International Conference on Islamic Economics and Finance. p. 19-21.

Hesse, Heiko and Martin Čihák. (2007). "Cooperative Banks and Financial Stability," IMF Working Paper No. 07/02 (Washington: International Monetary Fund).

(2008). Islamic banks and financial stability: An empirical analysis. IMF Working Papers, 1-29.

(2010). Islamic banks and financial stability: An empirical analysis. Journal of Financial Services Research, 38(2-3), 95-113.

Iqbal, Zubair and Abbas Mirakhor, 1987, "Islamic Banking," International Monetary Fund Occasional Paper 49 (Washington: International Monetary Fund).

Johnes, J., Izzeldin, M., \& Pappas, V. (2014). A comparison of performance of Islamic and conventional banks 2004-2009. Journal of Economic Behavior \& Organization, 103, S93S107.

Laeven, Luc, and Ross Levine, 2005, "Is There a Diversification Discount in Financial Conglomerates?" Journal of Financial Economics, forthcoming.

Maechler, Andrea, Srobona Mitra, and DeLisle Worrell, 2005, "Exploring Financial Risks and
Vulnerabilities in New and Potential EU Member States," Second Annual DGECFIN Research Conference: "Financial Stability and the Convergence Process in Europe," October 6-7, 2005

Mokhtar, H. S. A., AlHabshi, S. M., \& Abdullah, N. (2006). A conceptual framework for and survey of banking efficiency study. Unitar e-Journal, 2(2), $1-19$

Siddiqi, MN. (2000) "Islamic Banks: Concept, Percept and Prospects" Review of Islamic Economics 9, 21-36

Warjiyo, P. (2006). Stabilitas sistem perbankan dan kebijakan moneter: keterkaitan dan perkembangannya di Indonesia. Buletin Ekonomi Moneter dan Perbankan, 8(4), 429-454.

Yeyati, E. L., \& Micco, A. (2007). Concentration and foreign penetration in Latin American banking sectors: Impact on competition and risk. Journal of Banking \& Finance, 31(6), 1633-1647.

Table 1: Test of Equality of Mean

\begin{tabular}{|lcc|}
\hline Variable & $\begin{array}{l}\text { Islamic } \\
\text { Banks }\end{array}$ & $\begin{array}{l}\text { Conventional } \\
\text { Banks }\end{array}$ \\
\hline $\begin{array}{l}\text { Z-Score } \\
\text { Credit to Asset }\end{array}$ & 12.807 & $41.148^{* * *}$ \\
$(\%)$ & $70.402 * * *$ & 64.797 \\
$\begin{array}{l}\text { Cost to Income } \\
(\%)\end{array}$ & $88.369 * *$ & 84.677 \\
$\begin{array}{l}\text { Income Diversity } \\
\text { Total Asset }\end{array}$ & 0.22 & 0.23 \\
(Trilyon Rp) & 23.8 & $49.03 *$ \\
\hline
\end{tabular}

Source: Author calculation

Note: The difference between value of commercial and Islamic bank at 95\% confidence level is significant at $10 \%(*)$; at $5 \%(* *)$; at $1 \%(* * *)$ 
Table 2: Descriptive Statistic for ROA and EA

\begin{tabular}{lcc}
\hline & $\begin{array}{c}\text { Islamic } \\
\text { Banks }\end{array}$ & $\begin{array}{c}\text { Conventional } \\
\text { Banks }\end{array}$ \\
Mean & 1.12 & 1.56 \\
ROA & & \\
Stdev & 0.49 & 0.20 \\
ROA & 9.41 & 14.95 \\
Mean E/A & 9 \\
\hline
\end{tabular}

Source: author calculation

Table 3: Stationarity Test for Z Score

\begin{tabular}{lccc}
\hline Z Score & $\begin{array}{c}\text { Test for } \\
\text { unit root } \\
\text { in }\end{array}$ & $\begin{array}{c}\text { ADF t } \\
\text { Stat }\end{array}$ & $\begin{array}{c}\text { Critical } \\
\text { Value (5\%) }\end{array}$ \\
\hline \hline Islamic & & & \\
$\begin{array}{l}\text { Banks } \\
\text { Conv }\end{array}$ & Level & 1.928869 & 2.963972 \\
Banks** & Level & 3.046459 & 2.957110 \\
\hline \hline
\end{tabular}

Source: Author Calculation

Table 4: Regression Result (Fixed Effect Model)- Dependent Variable: Z Score

\begin{tabular}{lcc}
\hline Variable & Coefficient & P Value \\
\hline \hline Islamic Dummy & $-24.392^{* * *}$ & 0.000 \\
Asset & $4.808^{*}$ & 0.054 \\
Credit to Asset (CA) & -0.0157 & 0.750 \\
Cost to Income (CI) & $-0.0658^{*}$ & 0.078 \\
Income Diversity (ID) & 3.151 & 0.645 \\
Income Diversity-Islamic & 0.3024 & 0.969 \\
Constant & 38.9341 & 0.000 \\
Observation & 260 & \\
R-squared & 0.8842 & \\
\hline \hline
\end{tabular}

Source: Author calculation 